\title{
Screening for Asymptomatic Urine Abnormalities among Primary School Children in Qallin City of Kafr El-Sheikh Governorate,Egypt
}

\author{
Hala Mohammed Shaheen ${ }^{1}$, Safa Hamdy Elkalash ${ }^{1}$, Rasha Yousef Salama ${ }^{2}$ \\ ${ }^{1}$ Family Medicine department, Faculty of Medicine, Menoufia University \\ ${ }^{2}$ Ministry of Health and Population, Kafr El-Sheikh Governorate
}

\begin{abstract}
:
Background: Chronic kidney disease is cause of death and disability. Urine dipstick is a simple, non-invasive cost effective method with high ability to detect urine abnormalities in earlier stages for proper management and prevention. Objectives: 1-To assess prevalence of urine abnormalities. 2- To compare positive results of urine dipstick test with microscopic examination of urine.Methods: A sample of 320 students was randomly selected from two primary schools in Qallin city in Kafr El- sheikh governorate by simple random sampling technique. Students were assessed through a predesigned questionnaire to determine socioeconomic status of studied group. Urine dipstick was performed for each studied child to examine the morning urine sample. Another urine sample was taken from children who had abnormal urine dipstick results for complete microscopic urine analysis. Results: There was $15 \%$ from all the studied children having urine abnormalities during screening by dipstick test. The most prevalent abnormalities were hematuria, lecocyturia, nituria and lastly proteinuria $9.7 \%, 7.5 \%, 2.2 \%$ and $0.9 \%$ respectively. The most common abnormality in microscopic urine examination was crystaluria. Cases were +ve for urinary tract infection by dipstick confirmed by $67 \%$ were +ve for pus by microscopic analysis, while $9.6 \%$ of cases who were +ve for hematuria by dipstick screening confirmed by $100 \%+v e$ for blood by microscopic analysis.Conclusion: Prevalence of urine abnormalities was $15 \%$ among studied group. The most prevalent abnormalities were hematuria in dipstick test and crystalluria in microscopic examination.
\end{abstract}

Keywords: Screening, hematuria, lecocyturia, nituria.

Introduction:Chronic kidney disease (CKD) is defined as a reduced glomerular filtration rate, increased urinary albumin excretion, or both .It is an increasing public health problem. Prevalence is estimated to be 8-16\%worldwide. CKD is an important cause of death and disability. However, awareness is low among health-care staffs and patients. ${ }^{(1)}$ Early diagnosis and early treatment of renal diseases prevent kidney failure. As persons who have silent renal diseases usually not discovered until reaching an advanced stage, ${ }^{(2)}$

prevention of renal diseases is very important due to decreased financial resources, as dialysis centers, equipment and trained personnel are simply not available to the general population. ${ }^{(3)}$

Urinary screening is a very useful tool in early detection of occult urinary abnormalities, and so give chances for early proper management and prevention of irreversible complication or deterioration of kidney function and decreasing prevalence of *Corresponding author: E-mail: rasha2020salama@gmail.com 
end stage kidney disease (ESKD). ${ }^{(4)}$ Dipstick urinalysis (DUA) is considered the cornerstone to evaluate the renal function, as it is a simple, cheap, noninvasive test with high sensitivity and specificity to urine abnormalities. In Asia, an annual screening program for urine abnormalities among primary school children takes place in many countries as Japan, Taiwan, and Korea. ${ }^{(5)}$

The prevalence of urinary abnormalities in Egypt detected by dipstick test had the range from $1.3 \%$ to $16.4 \% .{ }^{(6)}$ This study aimed to estimate the prevalence of asymptomatic urinary tract abnormalities among primary school children, and comparing positive results of urine dipstick test with microscopic examination in Qallin city in Kafr El Sheikh Governorate.

Methods:The study is a cross sectional study. It was approved by Ethical Committee in Faculty of Medicine, Menoufia University; an official permission letter was obtained and directed to general director of education in Qallin district, Kafr El Sheikh Governorate. Written consents were granted to headmasters of selected schools. After illustration of study objectives, they were encouraged to give full informed consent to participate, and then written consents were taken from the parents to allow students participation. A legal permission was obtained from the manager of Qallin Central Hospital to perform complete urine examination in its laboratory. The study was conducted in the context of time frame 20 months from the end of February 2017 to the end of October 2018.

Sample size was calculated based on the prevalence of urinary abnormalities in the past review of literature conducted by Vinoth et al. $2015,{ }^{(7)}$ The sample size has been calculated at CI 95\%, power 80\%, It was 290 students and increased to be 320 (three hundred and twenty) apparently healthy students .Two primary schools out of six schools were selected to conduct the study by simple random sampling technique .Then children were chosen from both schools by the same technique at different grades with age range from 6 to 11 years old through proportionally allocation according to the total number of children in each school.

All students who participated in the study were evaluated using a predesigned questionnaire through directed interview with them and their parents. This questionnaire included questions about sociodemographic data including: Age, sex, family size, father`s work, mother`s work, father`s education, mother`s education for assessment of 
socioeconomic status according to Fahmy et al. ${ }^{(8)}$ The day before screening, parents were instructed about how to obtain the child's urine specimen. Tubes containing about $50 \mathrm{ml}$ of first early morning urine samples were brought by parents to school. Microscopic examination was conducted for positive urine samples by dipstick to hematuria, lecocyturia, proteinuria or nituria. Children with positive results in microscopic examination referred to Health Insurance Hospital for further management. Prevalence of abnormal urine findings using dipstick tests (leucocytes, nitrate, turbidity and blood), percentage of microscopic abnormalities according to dipstick results were the main study variables.

Data mangment: Data were collected, tabulated, statistically analyzed using using SPSS program (Statistical Package for Social Sciences) version 20. Analysis is conducted on two steps:

- Descriptive part: qualitative data were expressed and quantitative variables, mean and standard deviation were presented.

- Analytical part: Chi-square test was used for comparison of categorical variables. P value less than 0.05 was considered statistically significant and less than 0.001 was considered highly significant.

Results: The sociodemographic data of the participants: The mean age of the studied group was $(8.4 \pm 1.6)$. More than half of the participant was female (54\%).Moderate socioeconomic level contributed $63.1 \%$ of participants (table 1). Urine abnormalities were found among 15\% of studied children (figure1). Regarding the results of dipstick 9.7\% of them had hematuria, $7.5 \%$ had leukocytes in urine, $3.1 \%$ of children had turbidity in urine, $2.2 \%$ were positive in nitrate test and lastly $0.9 \%$ had proteinuria (table 2).

Children who were positive for urine abnormalities in dipstick screening showed positivity in microscopic examination. Microscopic examination showed that $27.1 \%$ had turbidity, $12.5 \%$ had microscopic hematuria ( $\mathrm{RBC} \geq 5$ cells $/ \mathrm{hpf}$ ), $68.8 \%$ of studied group had pyurea (pus cells $\geq 5$ cells/hpf ), and $85 \%$ had positive amorphous urate crystals(figure2) .Uric acid were detected in $12.5 \%$ of the sample and calcium oxalate were detected in $6.3 \%$ of the studied samples. Only $2.1 \%$ of the sample has positive phosphates as well as triple phosphates (figure2). 
Cases were +ve for urinary tract infection(leucocytes and nitrate), nitrate and leucocytes by dipstick showed positivity for pus by microscopic analysis in 67\%, 0\%, and $33.3 \%$ respectively(table 3). While $9.6 \%$ of cases who were +ve for hematuria by dipstick screening showed the same results by microscopic analysis as $100 \%$ of them were + ve for blood by microscopic analysis (table 4).

Discussion: Study was done upon apparently healthy children, who had not any urine abnormalities. Prevalence of urine abnormalities in primary school children in Qallin city was about $15 \%$ (Figure1). It was agreed with results of a study that was conducted in El-Gharbiya governorate by Zein El-Abden et al. 2016 which concluded that $16.4 \%$ of studied children had urinary abnormalities. ${ }^{(6)}$ Similarity of both results may be due to the location of both governorates as both governorates are contiguous area in the Delta.

This result was in controversy with results of studies were done in Dakahlia governorate by Bakr et al. 2007, and in Sohage governorate by Mahmoud et al. 2016, which reported that urinary abnormalities were $(1.3 \%, 1.86 \%)$ respectively ${ }^{(9)(10)}$, Which can be explained by a distance time in the $1^{\text {st }}$ study and a distance location in the $2^{\text {nd }}$ study with variations in socioeconomic status and nutritional habits. In Africa a study done by Akor et al. 2009 in Nigeria reported that urinary abnormalities were $9.6 \% .{ }^{(11)}$ Variation in results may be due to differences of population culture, habits and socioeconomic status.

The results concluded that hematuria was the most common dipstick abnormalities detected in $9.7 \%$ of the studied group (table 2). The most important causes of hematuria in young age are renal stones, structural abnormalities of the urinary tract, or parenchymal renal diseases. ${ }^{(12)}$ These results were in agreement with the Egyptian studies done by ElShafie et al. 2014 and Mahmoud et al. 2016 in Menoufiya and Sohage Governorates respectively ${ }^{(13,10)}$, and in other countries such as Lebanon ${ }^{(5)}$, India ${ }^{(14,15)}$ and Bolivia ${ }^{(16)}$, as hematuria was the most common abnormality. Urinary tract infection was the second most common finding in present study as leucocytes and nitrate were positive in $7.5 \%$ and $2.2 \%$ respectively, while proteinuria was detected only in $0.9 \%$. These results were in agreement with Mahmoud et al. 2016 study in Sohage Governorate who reported that $0.74 \%$ had hematuria, followed by $0.49 \%$ had pyuria and lastly $0.11 \%$ had proteinuria. ${ }^{(10)}$ 
Results of the current study differed from other studies done in Iran, Suadia Arabia, Vitnam , and Nigeria. As Shajari et al. 2013 in Iran and Akor et al. 2009 in Nigeria reported that the most common form of urinary abnormalities was proteinuria in $3.6 \%$ and followed by hematuria in 1\% ${ }^{(3)}$, while Al-Mendalawi, 2015 in Suadia Arabia and Doan et al. 2013 in Vitnam reported that the most common dipstick abnormality was positive nitrate, as Western Saudi Arabia nitrate was positive in $18.1 \%$, while in Vitnam nitrituria and leucocyturia accounted for more than $50 \%$ of the abnormalities. ${ }^{(17,18)}$

The most common abnormality in microscopic urine examination was crystals, as $85 \%$ had positive amorphous urate crystals, uric acid were detected in $12.5 \%$ of the sample, calcium oxalate in $6.3 \%$, and only $2.1 \%$ of the sample has positive phosphates as well as triplephosphates (figure2). These results were in agreement with El-Abden et al. 2013 and Al-Mendalawi, 2015 as the most common abnormality in microscopic urine examination was crystals in $(3.8 \%$ and $13 \%)$ of the studied groups respectively. ${ }^{(6)(17)} \quad$ Also crystals was the most common abnormality in El-Shafie et al. who reported that in confirmatory tests $83.10 \%$ of cases with hematuria in dipstick screening had hypercalciuria. ${ }^{(13)}$ The high prevalence of crystallurea in school children in many studies mostly due to bad nutritional habits among children.

A statistically significant difference was found between dipstick and microscopic analysis of urine regarding urinary tract infection(leucocytes and or nitrate) as $67 \%$ of cases who were +ve for urinary tract infection by dipstick, were +ve for pus by microscopic analysis with p-value 0.003 (table 3). It was in agreement with El-Shafie et al. as positive cases of UTI (leucocytes and or nitrate) by the dipstick were confirmed with $82.6 \%$ in microscopic examination. ${ }^{(13)}$ Marques et al. 2017 reported that $85 \%$ of positive nitrite or positive leukocyte esterase tests had confirmed with complete microscopic examination, which also in agreement with our study. ${ }^{(19)}$ Also, Marques et al. 2017 reported that $28 \%$ of cases who had positivity to nitrite and $79 \%$ of positive cases to leucocytes esterase by dipstick had confirmed with microscopic examination ${ }^{(19)}$ which were higher slightly than the results of the present study as no cases of positive nitrate by dipstick was positive for pus cells by microscopic examination, while $33.3 \%$ of cases who were positive to leucocytes esterase in dipstick test showed pus cells in microscopic examination (table 3 ). 
A statistically significant difference was detected between dipstick and microscopic analysis of urine regarding hematuria as $9.6 \%$ of cases were +ve for blood by dipstick screening showed the same results by microscopic analysis as $100 \%$ of them were +ve for blood by microscopic analysis with $\mathrm{p}$-value(0.008) (table 4). It was in little difference with El Shafie et al. as it was $97.5 \% .^{(13)}$

Study limitations: Some limitations of this study should be addressed.

- Some parents refused to participate in the study.

- Some samples were spilled from parents and the test was delayed until the next day to obtain a new specimen.

These obstacles' were overcome through:

- 1-Explaining what the urinalysis screening test means and its importance in early discover of renal diseases to the parents of children.

- 2-Recollecting of urine sample which were spilled in the next day.

Conclusion and Recommendations: This study showed that frequency of urine abnormalities was $15 \%$ among symptomatic primary school children. The most common abnormalities were hematuria, leucocyturia, nituria, and lastly proteinuria, which represented $9.7 \%, 7.5 \%, 2.2$ and $0.9 \%$ respectively. The most common abnormality in microscopic urine examination was crystaluria. Cases were +ve for urinary tract infection (leucocytes or nitrate) leucocytes, and nitrate by dipstick showed positivity for pus by microscopic analysis in $(67 \%, 33.3 \%$ and $0 \%)$ respectively. While $9.6 \%$ of cases who were +ve for hematuria by dipstick screening were all positive for blood by microscopic analysis.

Routine urine screening programs should be done for school children for early detection of renal diseases as a part of the school health program in primary schools. Children found to have urine abnormalities should undergo further evaluation and follow up should be done to detect the causes and predisposing factors for urinary abnormalities. Further studies involving other localities of Egypt including urban and rural areas, to compare the prevalence of urine abnormalities in different areas and the overall prevalence in Egypt.

Funding: All the costs were afforded by the researchers

Conflict of Interest: No Conflict of Interest to be declared 
Acknowledgement: The authors owe great and deep thanks to children, parents and teachers who participated in this work and from whom I learned much.

\section{References:}

1. Jha V, Garcia-Garcia G, Iseki K, Li Z, Naicker S, Plattner B et al. Chronic kidney disease: global dimension and perspectives .The Lancet 2013; 382(9888): 260-272

2. Collins A, Foley R, Gilbertson D, Chen S. United States Renal Data System public health surveillance of chronic kidney disease and end-stage renal disease. Kidney international supplements 2015; 5(1): 2-7

3. Shajari A, Fallah-zadeh M, Shajari H. Screening of renal diseases in the first primary school children in Shiraz. Acta Medica Iranica 2013; 45(3):215-218

4. Parakh P, Bhatta N, Mishra O, Shrestha P, Budhathoki S, Majhi S et al. Urinary screening for detection of renal abnormalities in asymptomatic school children. Nephrourology monthly 2012; 4(3):551

5. Hajar F, Taleb M, Aoun B, Shatila A. Dipstick urine analysis screening among asymptomatic school children. North American journal of medical sciences. 2011 ; 3(4): 179

6. El-Abden M, Abo-ElKheir O, El-Sadek S, El Said A, Awaad M. Screening of renal diseases by urine analysis in primary school aged children at El-Gharbiya governorateEgypt. Egyptian Journal of Hospital Medicine 2013: 50

7. Vinoth, P, Kumar, B, Chacko, B. Screening for asymptomatic renal disease among school children from Chennai City, India. Available at: Accessed April 2015: 19

8. Fahmy S, Nofal L, Shehata S, El Kady H, Ibrahim H .Updating indicators for scaling the socioeconomic level of families for health research. Journal of the Egyptian Public Health Association 2015 ; 90(1): 1-7

9. Bakr A, Sarhan A, Hammad A, Ragab M, Salama O, Al-Husseni F et al. Asymptomatic urinary abnormalities among primary school children in Egypt. World J Pediatr 2007; 3(3):214-217

10. Mahmoud R, El Masry A, Mohammad R, Yousef F. Urinary Screening for Detection of Renal Abnormalities in Asymptomatic School Children, Sohag Governorate, Egypt. British Journal of Medicine \& Medical Research 2016; 13(6):1-8 
11. Akor F, Okolo S, Agaba E \& Okolo A. Urine examination findings in apparently healthy new school entrants in Jos, Nigeria. South African Journal of Child Health 2009; 3(2):60-63

12. Alharthi A, Taha A, Edrees A, Elnawawy A, Abdelrahman A .Screening for urine abnormalities among preschool children in western Saudi Arabia. Saudi Medical Journal 2014; 35(12): 1477

13. El-Shafie A, El-Nemr F, Bahbah M ,Shokry M, Attia A. The role of urine screening in school children of Menoufiya Governorate in early detection of renal disorders. Journal of American Science 2014; 10:143-150

14. Chaudhury A, Reddy T, Divyaveer S, Patil K, Bennikal M, Karmakar K et al. A cross-sectional prospective study of asymptomatic urinary abnormalities, blood pressure, and body mass index in healthy school children. Kidney international reports 2017 ; 2(6): 1169-1175.

15. Srinivasulu K, Rao K, Kumar K .Urine Analysis as a Screening Tool in Early Detection of Renal Abnormalities in Asymptomatic School Children. World Journal of Nephrology and Urology 2018; 7(1): 17-24

16. Plata R, Silva C, Yahuita J, Perez L, Schieppati A, Remuzzi G. The first clinical and epidemiological programme on renal disease in Bolivia: a model for prevention and early diagnosis of renal diseases in the developing countries. Nephrology, dialysis, transplantation: official publication of the European Dialysis and Transplant Association-European Renal Association 1998; 13(12): 3034-3036

17. Al-Mendalawi M. Screening for urine abnormalities among preschool children in Western Saudi Arabia. Saudi Medical Journal 2015;36(3): 371

18. Doan T, Doan N, Pham T, Smets F, Thi M, Janssen F et al. Epidemiological urinalysis of children from kindergartens of Can Gio, Ho Chi Minh City-Vietnam. BMC pediatrics 2013;13(1):183

19. Marques A, Pasternak J, Damascena M, França C, Martino M .Performance of the dipstick screening test as a predictor of negative urine culture. Einstein (São Paulo) 2017;15(1):34-39 
Table (1): Sociodemographic characteristics of the studied group

\begin{tabular}{|c|c|c|}
\hline Sociodemographic characteristics & No (320) & $\%$ \\
\hline Age $($ mean \pm SD) & \multicolumn{2}{|l|}{$8.4 \pm 1.6$} \\
\hline Mother's education & & \\
\hline - Literate certificate & 2 & 0.6 \\
\hline - Primary & 7 & 2.2 \\
\hline - Preparatory & 9 & 2.8 \\
\hline - Secondary & 92 & 28.8 \\
\hline - University and Postgraduate & 210 & 65.6 \\
\hline \multicolumn{3}{|l|}{ Father's education } \\
\hline - Illiterate/read and write & 1 & 0.3 \\
\hline - Primary & 2 & 0.6 \\
\hline - Preparatory & 14 & 4.4 \\
\hline - Secondary & 75 & 23.4 \\
\hline - University and Postgraduate & 228 & 71.3 \\
\hline \multicolumn{3}{|l|}{ Mother's work } \\
\hline - No & 184 & 57.5 \\
\hline - Yes & 136 & 42.5 \\
\hline \multicolumn{3}{|l|}{ Father's work } \\
\hline - No & 4 & 1.3 \\
\hline - Yes & 316 & 98.8 \\
\hline \multicolumn{3}{|l|}{ Socioeconomic level: } \\
\hline - Low & 38 & 11.9 \\
\hline - Moderate & 202 & 63.1 \\
\hline - High & 80 & 25 \\
\hline
\end{tabular}




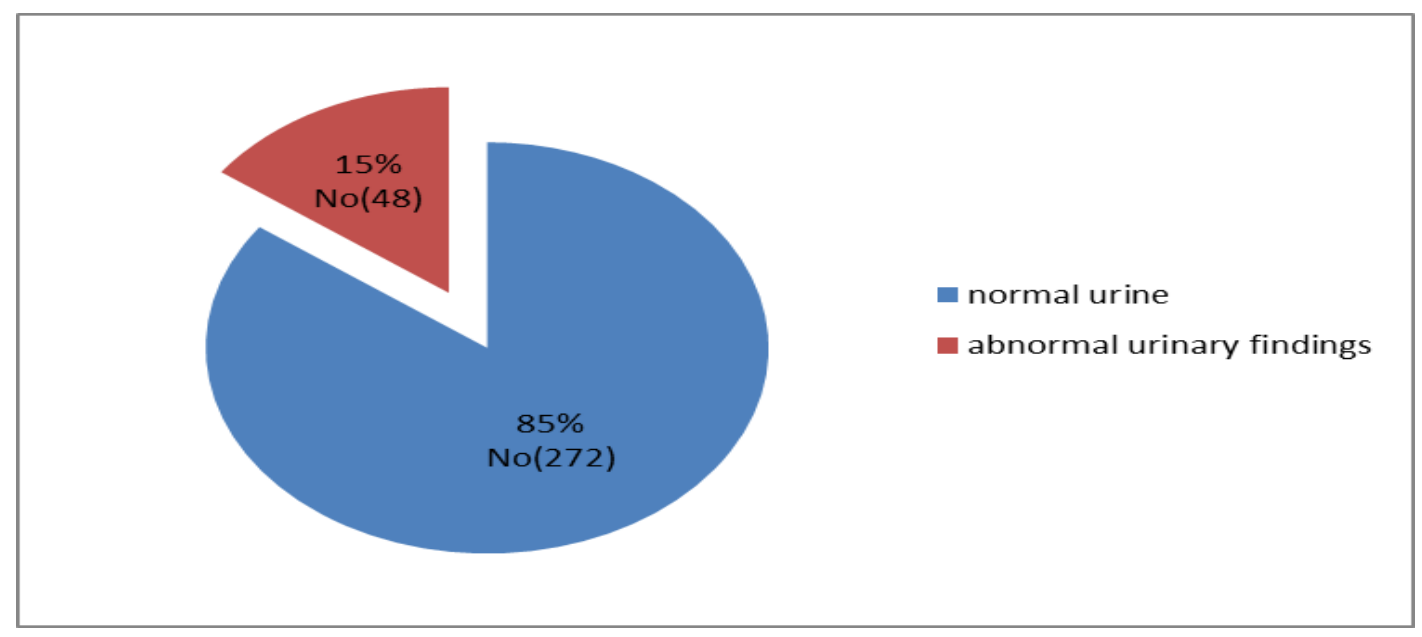

Fig (1): Prevalence of abnormal urine finding using dipstick screening tests

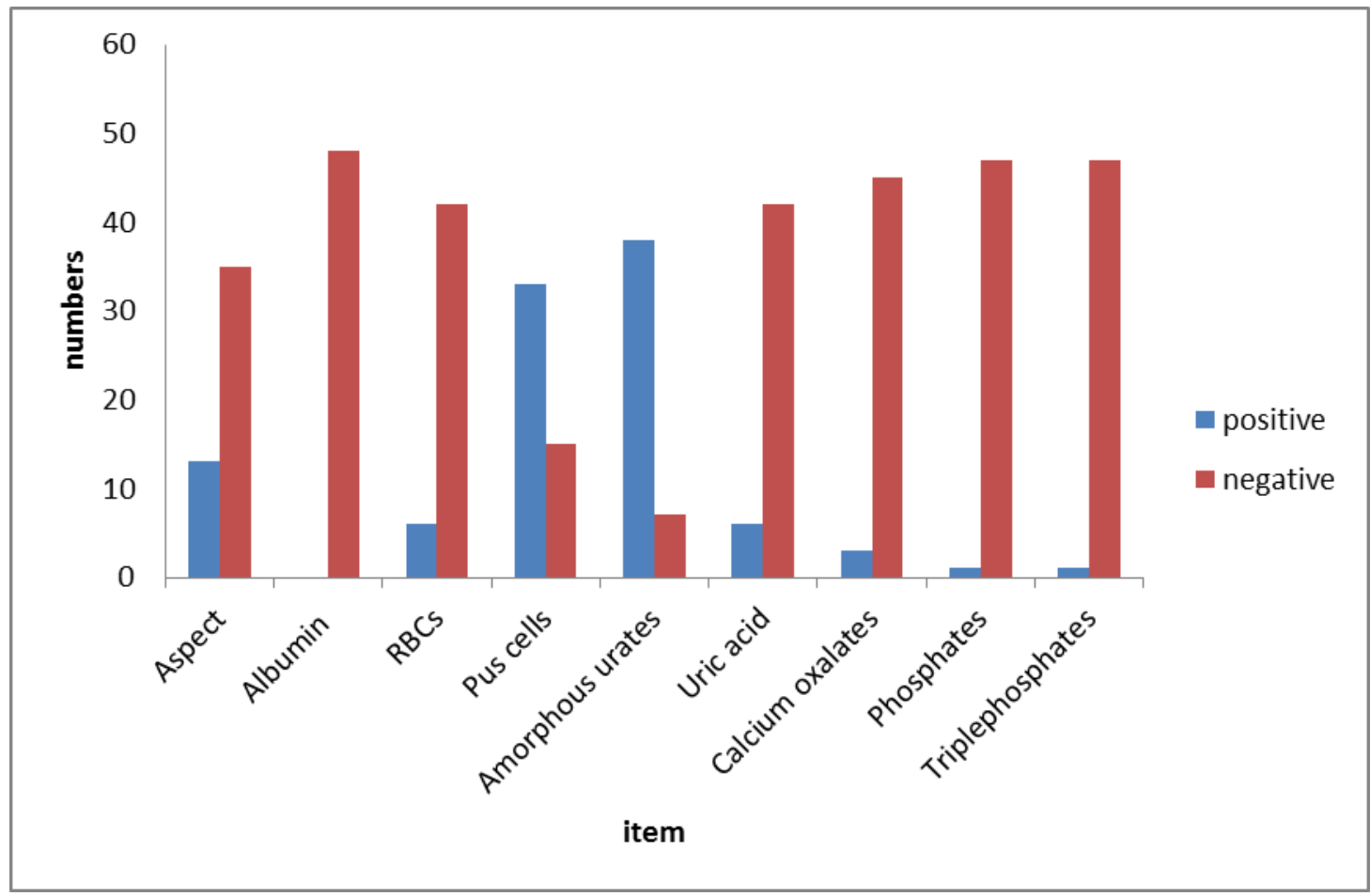

Figure (2): Percentage of microscopic Abnormalities according to dipstick results 
Table (2): Positive findings in urine of studied groups by urine dipstick

\begin{tabular}{|l|c|c|}
\hline Urine dipstick results & No of positive cases & \% of positive cases \\
\hline - Blood & 31 & 9.7 \\
- Leucocytes & 24 & 7.5 \\
- Turbidity & 10 & 3.1 \\
- Nitrate & 7 & 2.2 \\
- Proteins & 3 & 0.9 \\
\hline
\end{tabular}

Table (3): Comparing positive results of urine dipstick test regards (UTI, nitrate and leucocytes) with complete microscopic examination

\begin{tabular}{|c|c|c|c|c|c|c|c|c|}
\hline \multirow{2}{*}{\multicolumn{3}{|c|}{$\begin{array}{c}\text { Urine dipstick } \\
\text { results }\end{array}$}} & \multicolumn{4}{|c|}{ Microscopic examination } & \multirow[t]{3}{*}{$\mathbf{X}^{2}$} & \multirow[t]{3}{*}{ P-value } \\
\hline & & & \multicolumn{2}{|c|}{-ve (pus cells $<5)$} & \multicolumn{2}{|c|}{$+v e$ (pus cells $\geq 5$} & & \\
\hline & & & No & $\%$ & No & $\%$ & & \\
\hline \multirow{3}{*}{ 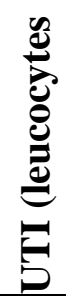 } & \multirow{3}{*}{ 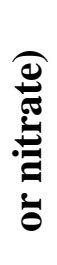 } & -ve & 12 & 80 & 11 & 33 & \multirow{3}{*}{8.99} & \multirow{3}{*}{0.003} \\
\hline & & $+\mathrm{ve}$ & 3 & 20 & 22 & 67 & & \\
\hline & & Total & 15 & 100 & 33 & 100 & & \\
\hline \multirow{3}{*}{ 营 } & & -ve & 35 & 83.3 & 6 & 100 & \multirow{3}{*}{1.17} & \multirow{3}{*}{0.31} \\
\hline & & $+\mathrm{ve}$ & 7 & 16.7 & 0 & 0 & & \\
\hline & & Total & 42 & 100 & 6 & 100 & & \\
\hline \multirow{3}{*}{ 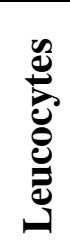 } & & -ve & 21 & 50 & 4 & 66.7 & \multirow{3}{*}{0.74} & \multirow{3}{*}{0.37} \\
\hline & & $+\mathrm{ve}$ & 21 & 50 & 2 & 33.3 & & \\
\hline & & Total & 42 & 100 & 6 & 100 & & \\
\hline
\end{tabular}


Table (4): Comparing positive results of hematuria by urine dipstick test with complete microscopic examination

\begin{tabular}{|c|c|c|c|c|c|c|c|}
\hline \multirow{3}{*}{ results } & \multirow{3}{*}{ Urine dipstick } & \multicolumn{4}{|c|}{ Microscopic examination } & \multirow[t]{3}{*}{$\mathbf{X}^{2}$} & \multirow[t]{3}{*}{ p value } \\
\hline & & \multicolumn{2}{|c|}{-ve $(\operatorname{RBCs}<5)$} & \multicolumn{2}{|c|}{$+v e(R B C s \geq 5)$} & & \\
\hline & & No & $\%$ & No & $\%$ & & \\
\hline \multirow[t]{2}{*}{ 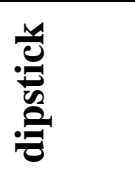 } & $-\mathrm{ve}$ & 17 & 40 & 0 & 0 & \multirow{3}{*}{3.76} & \multirow{3}{*}{0.008} \\
\hline & $+\mathrm{ve}$ & 25 & 60 & 6 & 100 & & \\
\hline 氖 & Total & 42 & 100 & 6 & 100 & & \\
\hline
\end{tabular}




\section{الملخص العربي}

\section{شر ائط الفرز البولي كاختبار للاكتشاف المبكر امراض الجهاز البولي غير ظاهره الاعراض بمدينة قلين محافظة كفر الثيخ- مصر الجراز البول}

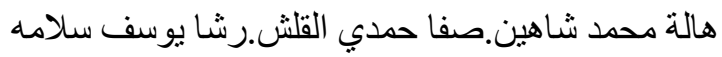

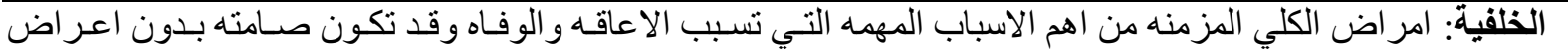

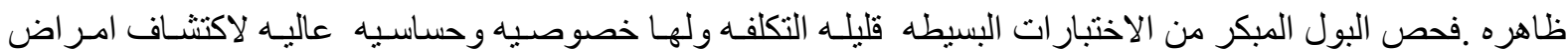
الجهاز البولي غير ظاهره الاعر اض في مر احل مبكره مما يتيح فرصه للعلاج ومنع المضاعفات. الأهداف: تم تقييم مدى

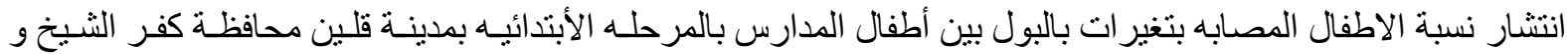
تحديد نوع التغيير ات الموجوده بفحص البول بينهمومقارنة نتائج فحص شر ائط الفرز بفحص الميكروسكوب. المنهجيـة و طرق البحث: تم اختيار الطلاب عشو ائيا من طلاب مدارس قلين الابتدائيه. خضعت المجموعة المدروسة لاستبيان مصسم مسبقا لتحديد البيانات الثخصيه و المجمعيه لمجموعة البحث ـ تم استخدام شر ائط الفرز لفحص عينة البول الصباحيه فى الأطفال و التى تشتمل على 10معايير و هي الحموضه ,الدم ,البروتين ,الكثافهـ ,السكر , الصـفر اء ,النيترات البكتيريـا او

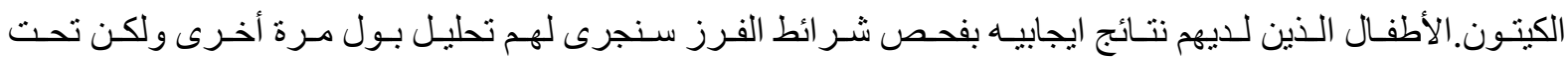
الميكروسكوب باستخدام فحص بول كامل.النتـائج: كـان مـا يقرب مـن 15 ٪ مـن الطـلاب لـيهم تغييـر ات بفحص البول المبدئي بشر ائط الفرز. وجد أن.7\%\% لديهم دم بفحص البول و7.5\% لديهم صديد و \% 3.1 لديهم تعكر بـالبول و 2.2\% لديهم بكتير ا واخير ا 0.9\% لديهم بروتين بالبول. معظم نتائج حالات فحص الميكروسكوب كانت ايجابيـه لوجـود الامـلاح بفحص الميكروسكوب. 67\% من حالات التهابات مجري البول التي تم اكتشافها بشر ائط الفرز البولي تم تأكيدها في فحص الميكروسكوب 100\% من حالات البول الـموى المحدده بشـر ائط الفرز تم تأكيدها بفحص الميكروسكوب.الخلاصـة: أظهرت هذه الدر اسة ان نسبه الاطفال المصابه بتغيير ات في فحص البول 15\% وبدون اعر اض ظاهريـه ـمعظمهم دم بالبول ويليهم صديد بالبول .كما ان نتائج شر ائط الفرز نم تاكيدها بنسبه عاليه بفحص الميكروسكوب . 